\title{
Natural Resources of Simalungun Regency for the Development of Micro, Small and Medium Enterprises
}

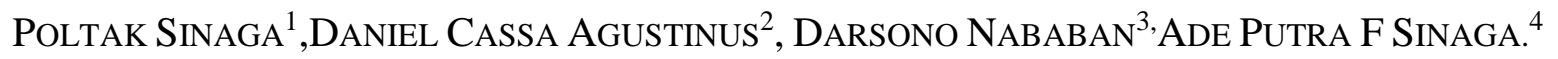 \\ WENNY YULIANITA SINAGA ${ }^{5}$ \\ ${ }^{1}$ Professor of Management, Universitas Pelita Harapan Jakarta /UISU Medan, INDONESIA \\ ${ }^{2}$ Universitas Pelita Harapan Jakarta, INDONESIA \\ ${ }^{3}$ Universitas Timor, INDONESIA \\ ${ }^{4}$ Universitas Prima Indonesia, INDONESIA \\ ${ }^{5}$ Health Office of Pakpak Bharat Regency \& Royal Prima Hospital /Universitas Prima Medan, \\ INDONESIA
}

\begin{abstract}
The Regency that rich in the natural resources needs many stake holders to attract the investors to open new enterprises or collaborate the Micro, Small and Medium Enterprises (SMEs). A map out procedure was carried ou to seek the natural resources as backbone of community development and business growth in Simalungun Regency of North Sumatra Province of Indonesia. Data collection was made by seeking the data of official documents and studies reports. Data obtained revealed that Simalungun Regency in 2019 and 2020 has a great economic growth in agriculture. It found that the sector of forestry, agriculture and fisheries in 2019 increases $6.15 \%$ and in 2020 it grew $9 \%$. Beside it has registered 1,200 SMEs, it will make the increase of SMEs whenever the Agropolitan Development Plan set up within 5 years. Simalungun Regency has very huge natural resources that needed to be developed as an agropolitan area to support the Micro, Small and Medium Enterprises (SMEs).
\end{abstract}

Keywords: agropolitan; Simalungun Regency; Enterprises; economic growth; business ; incomes

Received: August 3, 2020. Revised: February 3, 2021. Accepted: February 24, 2021.

Published: March 5, 2021.

\section{Introduction}

Natural resources are the big backbones for economic growth and new emerging the Micro, Small and Medium Enterprises (SMEs) in the Simalungun Regency. Viewing from the patterns of land use and livelihoods of the population, the Simalungun Regency could be described as area of rice fields. It has quite large land and most of the people in this Simalungun Regency still rely on the agricultural sector such as fisheries and livestock produces [1]. Refers to the natural resources and environment, the Simalungun Regency could have a good position [2] for business growth in future. The economic competitiveness of the Simalungun Regency increases if a map of natural resources set up better with the construction of physical infrastructure that still in a weight value of 0.221 [3]; it also has the regional economy with an assessment weight of 0.199 . Increasing the Simalungun Regency also need the human resources improvement [4]. Potential natural resources of Simalungun Regency which is part of the area at a cross position in the West Pacific Trench; it is geographically located between 02036'03018 'North Latitude and 98032'-99035' East Longitude [5]. Natural resources with many hot springs in Simalungun Regency; they are scatered in Kawah Putih Tinggi Raja, is precisely located in Silau Kahean 
Simalungun Regency, Dolok Marawa Village. Geothermal sources are found around 500 meters from residents [6]

The Simalungun Regency land area has potential and leading sectors in the fields of agriculture, plantation and tourism [7 and 8]. Based on the three important sectors, this study applied a data analysis procedure to obtain the natural resources of Simalungun Regency to increase the number of enterprises and economic growth of this regency.

\section{Problem Statement}

Due to the potential natural resources of Simalungun Regency of North Sumatra, this paper has three research problems;

1. How does Simalungun Regency have the potential natural resources as a backbone of economic and business perspective?

2. Does Simalungun Regency have a map of potential natural resources for economic and business development?

3. Does Simalungun Regency have promoted the potential natural resources for business growth?

\section{Research Procedure}

A qualitative research approach was applied to seeking the data of potentials natural resources of Simalungun Regency of North Sumatra Province of Indonesia. Data gathering with collection of official documents and reports of previously study was carried out. The sample is the natural resources of Simalungun that could be functioned as supporters the new enterprises. It map out the potent of natural and cultural resources of Simalungun Regency to lead the welfare of the Micro, Small and Medium Enterprises (SMEs). Data analysis used the proportion of the agricultural sector in Simalungun Simalungun Regency

\section{Data Finding}

The potential of natural resources in the Simalungun Regency could be seen from the patterns of land use and livelihoods of the community. The following tables show the natural resources and the use of land for plantation areas in Simalungun Regency.

Table 1. Plantation Areas in Simalungun Regency in 2020

\begin{tabular}{|c|l|c|}
\hline No & \multicolumn{1}{|c|}{ Type of business } & Large (Hectare) \\
\hline 1 & $\begin{array}{l}\text { a. Smallholder plantations } \\
\text { (in the form of oil palm, }\end{array}$ & $70.356,88$ \\
rubber, robust coffee, \\
arabica coffee, coconut, \\
cocoa, cinnamon, \\
hazelnut, pepper, sugar \\
palm, arecanut, vanilla, \\
tobacco, which are spread \\
in almost all districts
\end{tabular}




\begin{tabular}{|l|l|l|}
\hline 3 & $\begin{array}{l}\text { Large Foreign Private } \\
\text { Plantation / PBSA (in the } \\
\text { form of oil palm, rubber } \\
\text { and cocoa plantations }\end{array}$ & \\
scattered in Raya Kahean, \\
Bandar, Siantar, Pamatang \\
Bandar, Bandar Huluan \\
and Tapian Dolog \\
Districts) \\
\hline 4 & $\begin{array}{l}\text { National Private Large } \\
\text { Plantations / PBSN (in the } \\
\text { form of oil palm and } \\
\text { rubber plantations } \\
\text { scattered in the Districts of } \\
\text { Bosar Maligas, Tapian } \\
\text { Dolog and Tanah Jawa }\end{array}$ \\
\hline \multicolumn{2}{|c|}{ Total } \\
\hline
\end{tabular}

Source: RPI2JM, 2019. Simalungun Regency 2015 2019

Table 2.Statistics of Food Crops in Simalungun Regency 2018-2020

\begin{tabular}{|c|c|c|c|}
\hline Description & 2018 & 2019 & 2020 \\
\hline \multicolumn{4}{|l|}{ Rice Paddy } \\
\hline $\begin{array}{l}\text { Harvested } \\
\text { Area (Ha) }\end{array}$ & 71911 & 33303 & 62598 \\
\hline $\begin{array}{l}\text { Production } \\
\text { (Ton) }\end{array}$ & 447135 & 198109 & 336322 \\
\hline \multicolumn{4}{|l|}{ Corn } \\
\hline $\begin{array}{l}\text { Harvested } \\
\text { Area }(\mathrm{Ha})\end{array}$ & 58374 & 29992 & 41676 \\
\hline $\begin{array}{l}\text { Production } \\
\text { (Ton) }\end{array}$ & 339911 & 168158 & 234977 \\
\hline \multicolumn{4}{|l|}{ Soy } \\
\hline $\begin{array}{l}\text { Harvested } \\
\text { Area (Ha) }\end{array}$ & 124 & 4315 & 1004 \\
\hline $\begin{array}{l}\text { Production } \\
\text { (Ton) }\end{array}$ & 133 & 3047 & 1677 \\
\hline \multicolumn{4}{|l|}{ Peanuts } \\
\hline $\begin{array}{l}\text { Harvested } \\
\text { Area }(\mathrm{Ha})\end{array}$ & 522 & 587 & 685 \\
\hline $\begin{array}{l}\text { Production } \\
\text { (Ton) }\end{array}$ & 710 & 724 & 839 \\
\hline \multicolumn{4}{|l|}{ Cassava } \\
\hline $\begin{array}{l}\text { Harvested } \\
\text { Area (Ha) }\end{array}$ & 8441 & 4227 & 6416 \\
\hline $\begin{array}{l}\text { Production } \\
\text { (Ton) }\end{array}$ & 283657 & 137907 & 213319 \\
\hline \multicolumn{4}{|l|}{ Sweet potato } \\
\hline $\begin{array}{l}\text { Harvested } \\
\text { Area }(\mathrm{Ha})\end{array}$ & 1296 & 429 & 1200 \\
\hline Production & 20199 & 7418 & 22007 \\
\hline
\end{tabular}

(Ton)

Source: Plantation Office of Simalungun Regency

Table 3 Statistics of Smallholder Plantation Crops in Simalungun Regency

\begin{tabular}{|c|c|c|c|}
\hline Description & 2018 & 2019 & 2020 \\
\hline \multicolumn{4}{|l|}{ Rubber } \\
\hline $\begin{array}{l}\text { Harvested } \\
\text { Area }(\mathrm{Ha}) \\
\end{array}$ & 12675,10 & 5359,50 & 4460.69 \\
\hline $\begin{array}{l}\text { Production } \\
\text { (Ton) }\end{array}$ & 12142,60 & 2678,94 & 2506,09 \\
\hline \multicolumn{4}{|l|}{ Palm oil } \\
\hline $\begin{array}{l}\text { Harvested } \\
\text { Area }(\mathrm{Ha})\end{array}$ & 30097,70 & 30353,90 & 35958,59 \\
\hline $\begin{array}{l}\text { Production } \\
\text { (Ton) }\end{array}$ & $\begin{array}{l}287 \\
093,80\end{array}$ & $\begin{array}{l}518 \\
004,23\end{array}$ & $\begin{array}{l}555 \\
551,00 \\
\end{array}$ \\
\hline \multicolumn{4}{|c|}{ Robust coffee } \\
\hline $\begin{array}{l}\text { Harvested } \\
\text { Area }(\mathrm{Ha})\end{array}$ & 2441,30 & 1970,19 & 2096,85 \\
\hline $\begin{array}{l}\text { Production } \\
\text { (Ton) }\end{array}$ & 2155,60 & 703,53 & 819,79 \\
\hline \multicolumn{4}{|l|}{$\begin{array}{l}\text { Arabica } \\
\text { coffee }\end{array}$} \\
\hline $\begin{array}{l}\text { Harvested } \\
\text { Area }(\mathrm{Ha})\end{array}$ & 7876,00 & 8648,43 & 11219,61 \\
\hline $\begin{array}{l}\text { Production } \\
\text { (Ton) }\end{array}$ & 9743,50 & 5349,40 & 3583,45 \\
\hline \multicolumn{4}{|l|}{ Coconut } \\
\hline $\begin{array}{l}\text { Harvested } \\
\text { Area }(\mathrm{Ha})\end{array}$ & 2933,00 & 2044,23 & 3128,63 \\
\hline $\begin{array}{l}\text { Production } \\
\text { (Ton) }\end{array}$ & 2365,50 & 1879,04 & 2612,76 \\
\hline \multicolumn{4}{|l|}{ Chocolate } \\
\hline $\begin{array}{l}\text { Harvested } \\
\text { Area }(\mathrm{Ha}) \\
\end{array}$ & 5670,50 & 2283,80 & 1822,87 \\
\hline $\begin{array}{l}\text { Production } \\
\text { (Ton) }\end{array}$ & 5754,30 & 1030,08 & 852,94 \\
\hline \multicolumn{4}{|l|}{ Clove } \\
\hline $\begin{array}{l}\text { Harvested } \\
\text { Area }(\mathrm{Ha})\end{array}$ & 922,33 & 814,33 & 900,88 \\
\hline $\begin{array}{l}\text { Production } \\
\text { (Ton) }\end{array}$ & 55,94 & 113,87 & 105,87 \\
\hline \multicolumn{4}{|l|}{ Cinnamon } \\
\hline $\begin{array}{l}\text { Harvested } \\
\text { Area }(\mathrm{Ha}) \\
\end{array}$ & 374,6 & 279,69 & 436,25 \\
\hline $\begin{array}{l}\text { Production } \\
\text { (Ton) }\end{array}$ & 68,6 & 38,13 & 76,34 \\
\hline \multicolumn{4}{|l|}{ Candlenut } \\
\hline $\begin{array}{l}\text { Harvested } \\
\text { Area (Ha) }\end{array}$ & 432,3 & 398,58 & 431,08 \\
\hline $\begin{array}{l}\text { Production } \\
\text { (Ton) }\end{array}$ & 692,4 & 701,03 & 688,47 \\
\hline
\end{tabular}

Source: Plantation Office of Simalungun Regency 
Table 3 shows the agriculture production increased from 2018 to 2020. Compared to other sub-sectors, the fisheries sub-sector has quite a large potential in Simalungun Regency. The extent of agricultural land in Simalungun Regency is a potential land for livestock development [10]. It noted that Simalungun Regency from 2017 to 2019 has had the Association of Micro, Small and Medium Enterprises (SMEs) of Simalungun Regency. It has made the SMEs to produce the various flavours of coffees and coco, chips, crackers, woven fabrics, tea and coffee and so on. It also makes the Simalungun souvenir as one of the supporters of the food security program either in the Simalungun Regency or North Sumatra Province [11].

In 2017 it found that the lowest capital expenditure ratio of Simalungun Regency was $8.4 \%$ [12]. Comparison of the surplus or deficit in the 2018 and 2017 fiscal years in Simalungun Regency is 108.70 (in billion rupiahs) Spatially, the distribution of credit to project locations is concentrated in 7 districts in the Simalungun Regencys which reached IDR.4.7 trillion (2.2\%)[13]. The Simalungun Regency Government has 1,200 entrepreneurs as many as 525 SMEs have submitted requests for assistance from Pertamina [14]. Therefore, The souvenir house could be a media to promote and market the products of SMEs in Simalungun Regency [15].

The potential development of the mining and energy sector [16] could invite the foreign investment. Types of potential of metal and non-metal mining minerals in the Simalungun Regency are limestone, granite, granodiorite, quartz sand, marble, zeolite, feldspar, copper, limestone, mauve and andesite [17]. Thus this Regency also has the energy potential of several waterfalls. The waterfalls which can be used to generate energy include the Karai Waterfall 1-17 located in Silau Kahean, Simalungun Regency, Silau 1 and 2 Waterfalls in Hatonduhan Simalungun Regency. Another location such as Siporkas Waterfall and Nionggang Waterfall.

Fishery prospect is great in Simalungun Regency. The types of fish that have breeding in the Simalungun Simalungun Regency are tilapia and goldfish. These fish are generally get growing in some streams, ponds and floating net cages [18]. Some districts have huge fish production since 2015.

Thus mining materials found in Simalungun Regency vary in type and some of them have bright prospects for development, where the mining materials are mineral commodities as industrial raw materials and export commodities [19]. The potential of geothermal energy is an energy that is environmentally friendly and relatively cheap to use as a power plant [20].

The following figures show the economic growth since 2016. Industrial production and manufacture have increased since 2016 to 2020. It noted that in 2020 the fisheries, agriculture and farming have better growth than that of previous year (2019). 
Figure 1. Economic Growth of Simalungun Simalungun Regency 2016

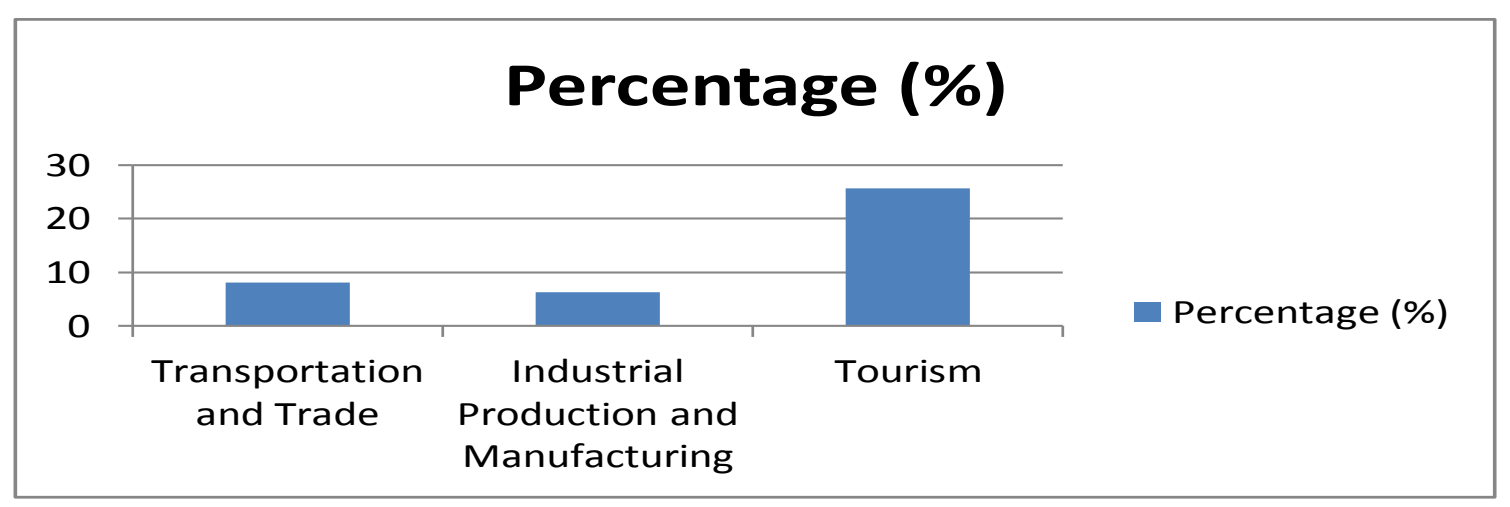

Data above shows that economic growth of the Simalungun Regency in 2016 has the tourism sector increases twenty six percent, second is transportation and trade, but industrial production and manufacturing only five percent; it is the lowest one.

Figure 2. Economic Growth of Simalungun Simalungun Regency 2017

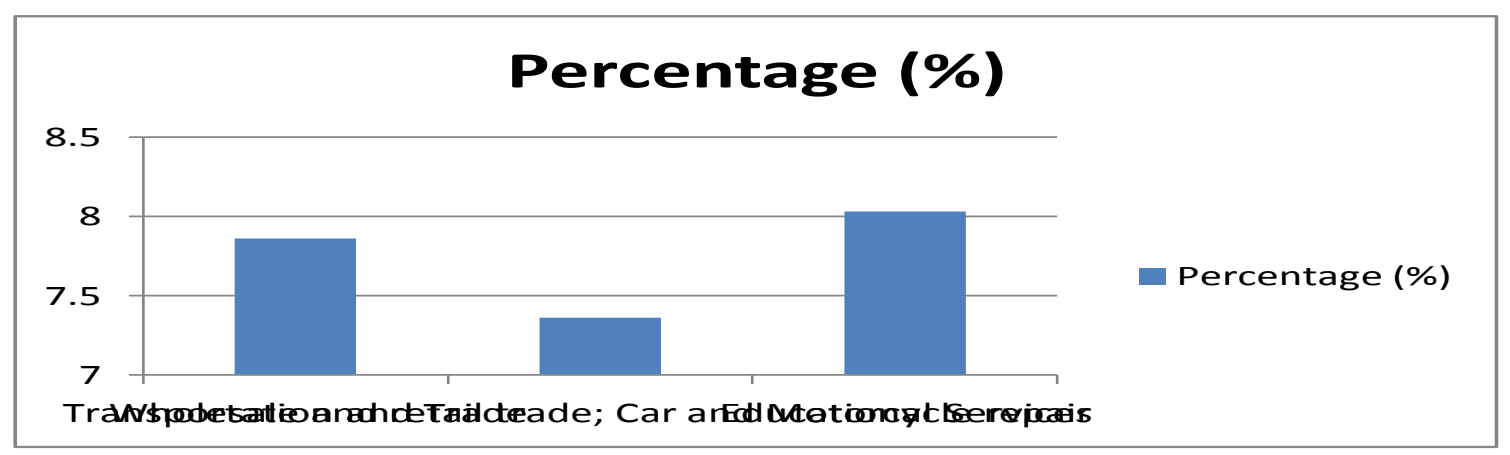

It found that educational services increase (8\%) in the Simalungun Regency in 2017, wholesale and retail trade ; Car and motor-cyle repair $7.3 \%$, transportation and trade increase $7.8 \%$.

Figure 3. Economic Growth of Simalungun Simalungun Regency 2018 


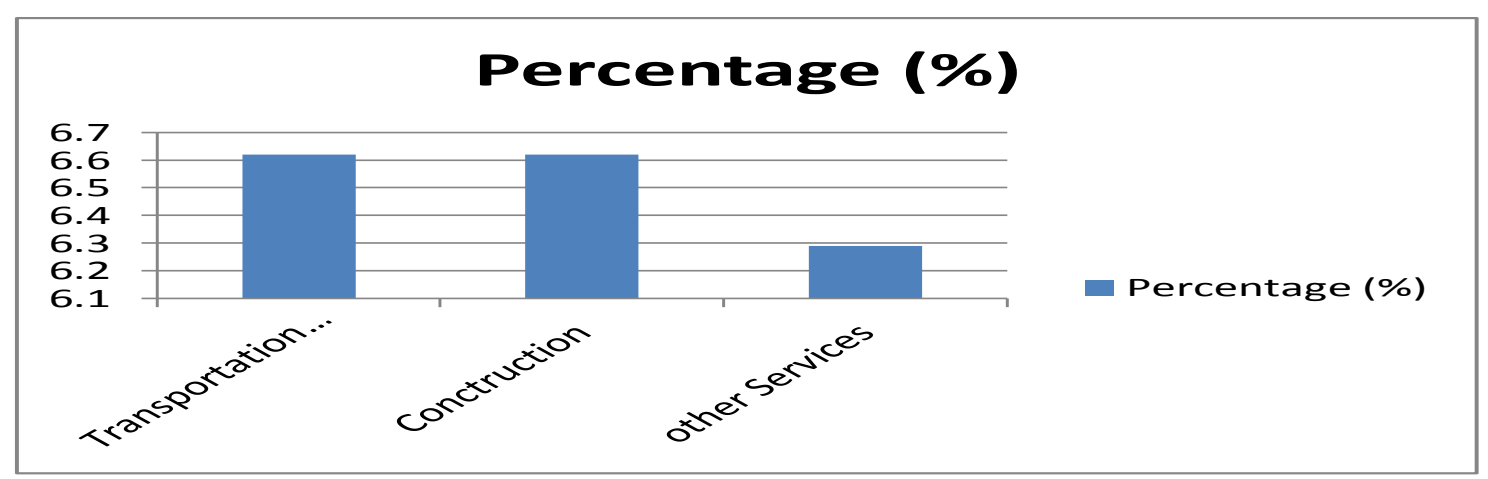

It indicates the construction has $6.63 \%$ increased in 2018, followed by transportation and trade $6.6 \%$, other is $6.27 \%$.

Figure 4. Economic Growth of Simalungun Simalungun Regency 2019

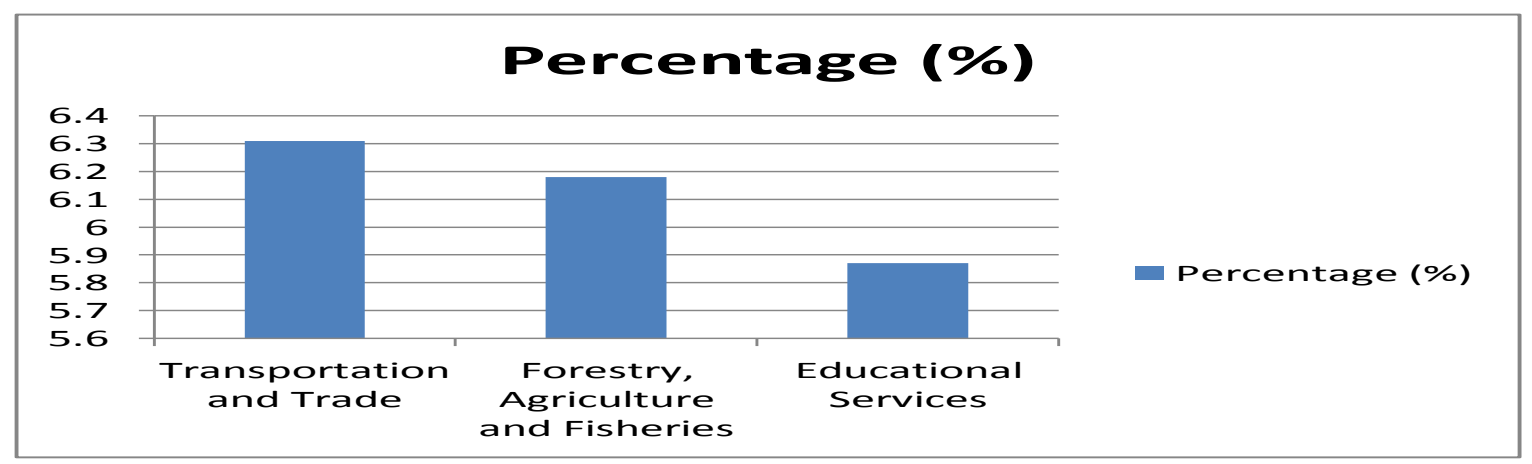

It shows that the sector of transportation and trade increase $6.3 \%$ in 2019 , it is the highest; 6.15 $\%$ of Forestry, agriculture and fisheries increase;

Figure 5. Economic Growth of Simalungun Simalungun Regency 2020

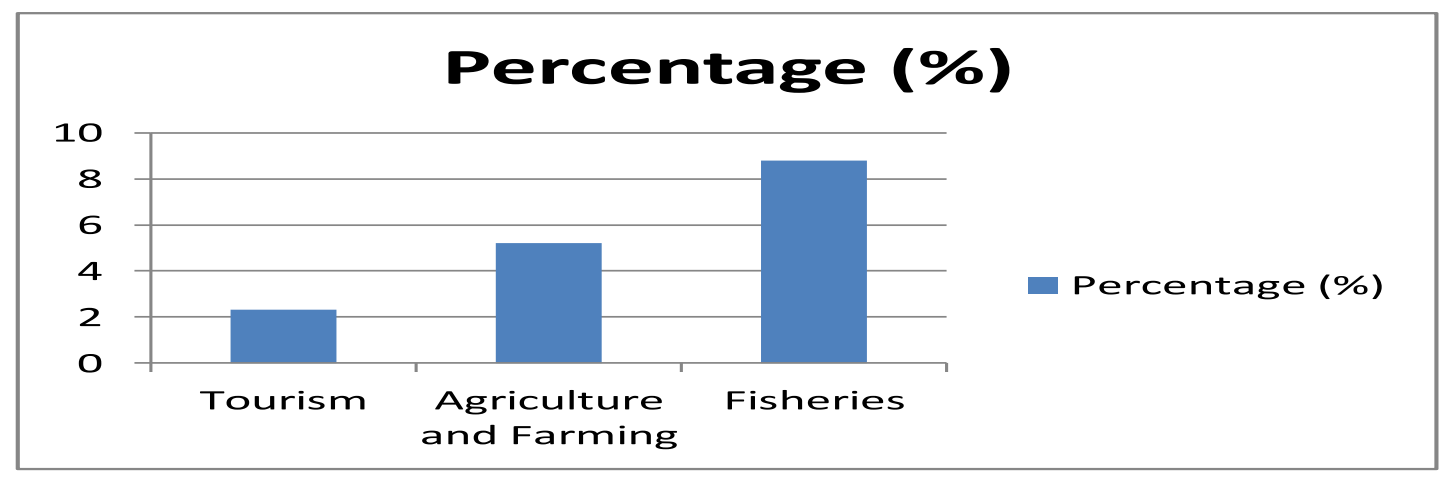

Data above shows that Fisheries sector grew 9 percent in 2020; Agriculture and farming $5 \%$, and tourism $2.2 \%$.

\section{Data Analysis}


The natural resources impact on the Simalungun Regency is great. It has a large area of rice fields and most of the people in this Simalungun Regency still rely on the agricultural sector. The Agriculture and farming and fisheries of Simalungun Regency in 2020 grew higher that of 2019. As agricultural land management in Simalungun Regency includes cultivated wet and dry land [21], we found the food crops, plantation, livestock, forestry and fisheries sub-sectors [22] increased. Besides having Lake Toba, the fishery area in Simalungun Regency also has ponds, rice fields, swamps and several rivers that are quite long which could be used for fisheries development. However, the fisheries business is generally a small scale household business [23].

It reported that the pattern of irrigation networks in Simalungun Regency is to follow the form of rice fields, with the irrigation network-level being fixed (T), semi-fixed (ST), drainage channel (SD) and village irrigation [24]. It indicated that the right strategy to leverage SMEs in Simalungun Regency is developing an agropolitan area. The agropolitan concept, it increases people's income according to the target set by the government. It is at the level of US \$3000 per year or IDR. $44,000,000$ per year, and it will be a huge amount since 2009 mapping [25]. Intensification of regional revenue sources in Simalungun Regency is directed at optimizing the management of existing revenue sources. It needs new sources of income that may be used as a source of income and by coordinating with the provincial and central governments in terms of increasing budget allocations.1. Apart from having a large area, Simalungun Regency also has fertile soils that are very suitable for agriculture [26]
2. The slow economic development in Simalungun Regency is one of the causes is the agricultural sector is not supported by the development of the industrial sector [27]

3. Simalungun Regency is an area that has a dominant economic structure in the agricultural sector, where the agricultural sector is located in rural areas. In order to support the agricultural sector, rural infrastructure development is a priority in development [28]

\section{Conclusions}

Data interpretation gives two important factors for Simalungun Regency development;

(1). This regency has very huge natural resources that needed to be developed as an agropolitan area to support the Micro, Small and Medium Enterprises (SMEs). It noted that Simalungun Regency from 2017 to 2019 has had the Association of Micro, Small and Medium Enterprises (SMEs) of Simalungun Regency. It shows that the sector of forestry, agriculture and fisheries in 2019 increases $6.15 \%$ and in 2020 it grew $9 \%$.

(2). Simalungun has a map of potential natural resources; it shows the agricultural land in Simalungun Regency is a potential land for livestock development. The types of fish that are cultivated in the Simalungun Simalungun Regency are tilapia and goldfish. These fish are generally cultivated from rivers, people's ponds and floating net cages.

(3). The effective promotion to the investors and multinational companies have been carried out by the Government of Simalungun Regency and a few privet companies and their associations. It still needs a new technique of promotion to increase the new companies in Simalungun Regency. 
References

[1] RPI2JM Simalungun Simalungun Regency. Simalungun Simalungun Regency Profile. Technical Support Rpi2jmkabupaten Simalungun 2015 2019 in the Implementation of Policies on Integration of Copyrighted Works Programs. 2019.

[2] Dinata, R.J. \& Hidayat, P. Economic Competitiveness Analysis in Simalungun, North Sumatera. Economic and Financial Journal, 3(1), 2016. 1-15

[3] Hidayat, P. Economic Competitiveness Analysis in the City of Medan, Economic and Bussiness Journal 4(3), 2012. 228-238

[4] Sirojuzilam \& Mahalli, K. Regional: Development, Planning and Economy, Medan: USU Press. 2010

[5] Central Bureau of Statistics Simalungun. Simalungun dalam Angka 2014, BPS Kabupaten Simalungun, Simalungun. 2014

[6] Ministry of Energy and Mineral Resources. Handbook of Energy \& Economic Statistic of Indonesia. PUSDATIN ESDM. Jakarta. 2014.

[7] Santoso, E.B. The Competitiveness of big Cities in Indonesia. A National Seminar on Urban Planning and City Planning, ITS, Surabaya. 2009.

[8] Simalungun Simalungun Regency Governement performance Report. In the Medium Term Development Plan Document of 2016-2021. 2016.

[9] Sidauruk, E. \& Simanungkalit, N.M. Analysis of Land Use Forms in the Simalungun Regency of Raya, Simalungun Regency, 2001 and 2011. Jurnal Tunas Geografi, 4(1), 2015. 18.

[10] Andika. Bupati dan Kapolres Simalungun Apresiasi Keberadaaan UMKM Penggerak Home Industri. waspada.id. 2020. https://waspadaid.cdn.ampproject.org/v/s/waspada.id/ sumut/bupati-dan-kapolressimalungun-apresiasi-keberadaanumkm-penggerak-home-industri

[11] APBD. Summary of APBD 2018. Directorate General of Financial Balance. 2018.

[12] Bank of Indonesia. Economic Report of North Sumatera Province. Bank Indonesia Representatives office, North Sumatera Province. 2019

[13] Mistar, H. Pandemi Covid-19, Realisasi Bantuan UMKM Simalungun Nihil. Waspada.id. 2020. https://www-mistar-

id.cdn.ampproject.org/v/s/www.mistar .id/siantar/pandemi-covid-19-realisasibantuan-umkm-simalungun-nihil/

[14] Manulang, W. Kapolres Simalungun AKBP Agus Waluyo SIK dan Bupati JR Saragih siap Mendukung UMKM di Kabupaten Simalungun. 2020. https://hariansib.com/beritaterkini/Kapolres-dan-Bupati-DukungPengembangan-UMKM-diSimalungun/

[15] Togatorop, S.P. Analysis of Changes in Land Use Forms in Pantai Labu SubSimalungun Regency, Deli Serdang Regency, 2004-2009. Skripsi. Medan: Fakultas Ilmu Sosial Universitas Negeri Medan. 2011.

[16] Berutu, L.D. Changes in Land Use Forms in Danau Paris Simalungun Regency, Aceh Singkil Simalungun Regency, 2005-2009. Skripsi. Medan: Fakultas Ilmu Sosial Universitas Negeri medan. 2011

[17] Manik, J.A. Map of Potential Population and Inter-City Interaction between Sub-Simalungun Regencys for Assessment of Doloksanggul City as the Capital of Humbang Hasundutan Regency. Skripsi . Medan. Fakultas 
Ilmu Sosial Universitas Negeri Medan. 2008.

[18] Sirait, M. Forms of Rural Land Use in Asahan Simalungun Regency, North Sumatra Province. Tesis. Yogyakarta: Fakultas Paska Sarjana Universitas Gadjah Mada. 1987.

[19] Akbar, N, et al. Symptoms of hot springs in Dolok Marawa, Kab. Simalungun, Sumut. 1972.

[20] Sugiharto. Regional Development and Development. Medan: USU Press. 2006.

[21] Irawati, I., Urufi, Z., Resobeoen, R.E., Setiawan, A., \& Aryanto. Measurement of Regional Competitiveness Based on Regional Economic Variables, Infrastructure and Natural Resources Variables and Human Resources Variables in Southeast Sulawesi Province, Prosiding INSAHP5, Semarang. 2008.

[22] Arsyad, S. Soil and Water Conservation. Bogor: IPB Press. 2010.

[23] Simanjuntak, D. Regional Potential in Developing Agropolitan Area in Samosir. Economic and Finacial journal 1,(3), 2013. 134-150

[24] Lubis, A. H., \& Salmiah, Negara, S. Income Distribution and Poverty Level of Arabica Coffee Farmers in Tanjung Beringin village, Dairi Simalungun Regency. Journal on Social Economic of Agriculture and Agribusiness, 1 (1), 2012.

[25] Sirojuzilam \& Mahalli, K. Regional: Development, Planning and Economy, Medan: USU Press. 2010

[26] Redo, E.S., Goa, A.M., Widiasri, M. 2019. Journaling Analysis of Determining Centers of Economic Growth in Simalungun Regency. Kanjuruhan University Malang. 2019.
[27] Tarigan, Robinson, 2010. Regional Development Planning, Revised Edition V, Publisher Bumi Aksara, Jakarta.

[28] RPI2JM Simalungun Simalungun Regency. Simalungun Simalungun Regency Profile. Technical Support Rpi2jmkabupaten Simalungun 2015 2019 in the Implementation of Policies on Integration of Copyrighted Works Programs. 2019.

\section{Creative Commons Attribution License 4.0 (Attribution 4.0 International, CC BY 4.0)}

This article is published under the terms of the Creative Commons Attribution License 4.0 https://creativecommons.org/licenses/by/4.0/deed.en_US 